\title{
Analyzing the Cost and Returns of Smallholder Farmers: A Case of Asante Akim South in Ghana
}

\author{
Evans Kingley Neizer ${ }^{1}$, Kofi Frimpong-Anin ${ }^{2} \&$ Paul Mintah $^{2}$ \\ ${ }^{1}$ Valley View University, Techiman Campus, Department of Agribusiness, P. O. Box 196, Techiman, Ghana \\ ${ }^{2}$ CSIR-Crops Research Institute, P. O. Box 3785, Kumasi, Ghana \\ Correspondence: Kofi Frimpong-Anin, Research Scientist (Entomologist/Pollination Ecologist), CSIR-Crops \\ Research Institute, P. O. Box 3785, Kumasi, Ghana. E-mail: nanakofy@yahoo.com
}

Received: December 31, 2017 Accepted: February 11, 2020 Online Published: February 22, 2020

doi:10.5539/sar.v9n2p67

URL: https://doi.org/10.5539/sar.v9n2p67

\begin{abstract}
Managing crop production as a business among smallholder farmers is a challenge. This farmers' survey therefore assessed farm activities and their economic implications to smallholder farmers, with special reference on cocoa farmers, using structured questionnaire. Farmers and their household were found to be greatly involved in providing labour for all key farm activities such as weed management, pesticide application and harvesting. This labour was not priced by most farmers and therefore estimated expenditure on managing the farms were lower than actual cost incurred. Cocoa formed $75 \%$ of total landholdings with 3-4 acres and < 3acres being the modal farm size for cocoa and supplementary crops (vegetables, plantain, oil palm, cassava and maize) respectively. Although applying fertilizer to cocoa increased yield by over $144 \%$, majority of the farmers did not consistently apply it due to purported high price. Vegetables were the only crop that fertilizer was consistently applied to, and even that it was below recommended rates. Yearly variable margin from cocoa treated with fertilizer was GHS 837 (US\$ 190)/acre compared to GHS 548 (US\$ 125)/acre of cocoa without fertilizer, thereby justifying the use of fertilizer. The annual variable margin from supplementary crops ranged GHS 162-274 (US\$37-62)/acre/year, depending on the type of crop. Based on the statistical mode of 4-6 persons per household, 3-4 acres of cocoa and 0.5-2.5 acres of supplementary crops, the yearly returns of GHS 2,511-3,348 (US\$ 570-761) from cocoa (with fertilizer) and GHS 81-685 (US\$ 18.41-155.68) from supplementary crops was inadequate. Promoting other low capital input ventures like snail rearing, mushroom production and bee keeping will be of immense support to the farmer's household.
\end{abstract}

Keywords: cocoa, crop, fertilizer, household, income, labour, vegetable

\section{Introduction}

Agriculture is the mainstay of many rural communities in developing countries, serving as main source of income, household staple needs and employment (Laven, 2010). In Ghana, 54\% ef households of the population depend on agriculture and in the forest regions, cocoa is the major cash crop cultivated (Ghana Statistical Service, 2013). As the second largest producer of cocoa in the world, one-third of its population comprising farmers, agrochemical producers and sellers, pesticide applicators, transporters, Licensed Buying Companies (LBCs), researchers, administrators, casual labourers, and seedling growers, are estimated to be directly depend on the cocoa industry (Buffin, Williamson \& Dinham, 2004; Laven, 2010). Estimated 800,000 smallholder cocoa farmers and their families source $70 \%-100 \%$ of their income from cocoa (Ghana Cocoa Board).

In spite of the importance of the crop globally, farmers who are core cocoa producers remain poor. This has attracted many research and debate among researchers and economic activists (Appiah, 2004; Hainmueller, Hiscox \& Tampe, 2011). Low adoption rate of scientific research recommendations, poor extension services, high cost of agricultural inputs, ageing cocoa farms and destruction by pests and diseases have been identified as some of the causes of low crop yield and subsequent poverty (Aneani, Achirinah, Owusu-Ansah \& Asamoah, 2012). Cocoa used to be a commodity for wealth creation in the early development years (prior to 1980s) of the crop in Ghana but the situation has changed over the years due to increased demand for labour and agro inputs in its cultivation. In those periods, fertile lands were in abundance, weather conditions were favourable, pests were easily managed with insecticides and labour was cheap. All that a farmer needed was to clear a patch of forest, plant seedlings and with little care the crop reaches bearing stage (Acquaah, 1999). The rising cultivation 
demand of the crop and drop in yield appear to have dwindled gains by farmers.

Governments, non-governmental organizations (NGOs) and international funding agencies have initiated many intervention projects to help reduce cost of farming and proper farm management in order to curb the endemic poverty among cocoa farmers. Amongst current government interventions in Ghana are the subsidizing fertilizers, mass spraying of cocoa farms, free distribution of precocious and high yielding cocoa seedlings, upgrading of feeder roads in cocoa growing areas.

Cocoa growers normally do not cultivate only cocoa but also other crops as alternative source of income and provision of food for their household. Thus, acquisition of additional income from regular salaries through a profession, vending and supplementary farming. All these give some understanding of the living standard and welfare of these smallholder farmers. Furthermore, the impact of introduced interventions on income status of household of farmers is appraised. It is however not clear if farmers appropriately cost farm expenditures in order to appreciate empirical gains by these interventions. Other studies suggest smallholder farmers do not keep records of farm expenses but most of these tend to focus only on a farming activity (e.g. a specific crop or cropping system) of interest and not the totality of gains, in considering all income sources. Critical to this study, therefore, was the distribution of farm labour, how farmers cost farm activities, impact of farming practices on income of farmers and the contribution of members to the upkeep of the farmers' household with special reference on smallholder cocoa farmers.

\section{Materials and Methods}

\subsection{Research Areas}

This study was carried out at Obogu (6 $\left.6^{\circ} 31^{\prime} 0^{\prime \prime} \mathrm{N}, 1^{\circ} 7^{\prime} 0^{\prime \prime} \mathrm{W}\right)$, Odubi $\left(628^{\prime} 32.2^{\prime \prime} \mathrm{N}, 1^{\circ} 5^{\prime} 10.2^{\prime \prime} \mathrm{W}\right)$ and Kumeso $\left(6^{\circ} 28^{\prime} 1.1^{\prime \prime} \mathrm{N}, 1^{\circ} 4^{\prime} 16.1^{\prime \prime} \mathrm{W}\right)$ and their satellite hamlets, in the Asante Akim South, Ashanti Region, Ghana. The area is within the forest belt with bimodal rainfall in March to July and September to November. It has a short dry spell from December to February. Respondents comprise of cocoa farmers from the two communities. Majority of the residents were mainly cocoa farmers but also grow plantain, oil palm, cassava, maize and vegetables (mainly tomato, pepper, garden egg and okra).

\subsection{Survey Questionnaire and Its Administration}

Information on farm management activities and cost of these activities was elicited from the farmers using a structured questionnaire adopted from Frimpong (2009), for assessing cocoa farm management cost. The questionnaire covered general farm management and reasons behind their choice of practices, sources and cost of labour, and alternative sources of income.

Purposive sampling of eighty households of cocoa farmers whose farms were at least 10 years old was conducted between October 2016 and January 2017. The minimum age of farm was based on the fact that cocoa starts to bear pods between 3 to 7 years after transplanting, depending on the variety. Each household was interviewed as a unit but where all members were not readily available, the farmer who was the prime respondent, and any available members were interviewed.

\subsection{Data Analysis}

Frequencies and percentages of responses of farm activities were computed. Responses on expenditures were in both monetary and man working days. However, data on monetary cost of farm activities were analysed by converting man working days (as farm labourer's wage per day) to monetary equivalence. Calculations of costs were based on mean amount paid per acre, and statistical mode of frequency of farm activities. The variable margin $(\mathrm{VM})$ for cocoa and the supplemental crops was calculated as:

$$
\mathrm{VM}=\mathrm{TR}-\mathrm{VC}
$$

Where, $\mathrm{TR}=$ Total revenue; $\mathrm{VC}=$ Variable costs

\section{Results}

The age of farmers interviewed ranged between 27 and 70 years, as a result of the 10 years old cocoa farm criteria used in selecting respondents. Males dominated (81\%) and the education levels were 35\%,39\% and 6\% for illiterates, basic and secondary school respectively. The statistical mode of individuals per household was $4-$ 6 persons (Table 1). Twenty-three percent of the cocoa farmers, who were also household heads depended solely on income from cocoa. Although cocoa was the prime source of income, majority (71\%) also relied on other crops with few gaining income as artisans (carpentry, masonry etc. and fod vending) (Table 2). The rest of the household members were mainly students $(60 \%)$ with no additional income support to the household. 
Table 1. Number of persons in a household

\begin{tabular}{lll}
\hline Number of persons & Frequency & Percent \\
\hline $\mathbf{1 - 3}$ & 28 & 34.92 \\
$\mathbf{4 - 6}$ & 35 & 43.71 \\
$\mathbf{7 - 9}$ & 17 & 21.37 \\
\hline
\end{tabular}

Table 2. Activities and alternative income sources of cocoa farmers' household

\begin{tabular}{lll}
\hline Activity/income source & Farmer (head) & Rest of household \\
\hline Other crops & 71 & 28 \\
Artisan & 29 & 16 \\
Public/civil service & 10 & 5 \\
Petty trading & 6 & 18 \\
None & 23 & 21 \\
Student & 0 & 60 \\
\hline
\end{tabular}

Farm landholdings were generally small with high proportion (47.50\%) of them having $3-4$ acres (Table 3). Majority (75\%) of the landholdings were cultivated to cocoa with 50\% of them ranging between 3 and 4 acres (Table 3). Varieties planted were mainly hybrids although the older farms (>20 years) have mixed amazonia and hybrid varieties. This was supplemented with subsistence plantain, oil palm (5\%); maize, cassava, cocoyam mixed crop (11\%) and vegetables (tomato, pepper, garden eggs, cabbage and okro) (9\%). Whilst 33\% of the cocoa farms were $10-20$ years old, $42 \%$ and $25 \%$ were $21-31$ and over 31 years respectively.

There were different ownership status of the cocoa farms. Proportions for full ownership/customary, rented and sharecrop (farmer cultivate the land and acquire a third of the farm as long as the cocoa remains on the land) were $51.70 \%, 16.00 \%$ and $32.30 \%$ respectively.

Table 3. Total farm landholdings and proportion cultivated to cocoa

\begin{tabular}{lll}
\hline Land size & \multicolumn{2}{l}{ Farm landholdings } \\
\cline { 2 - 3 } & Total & Cultivated to cocoa \\
\hline$<\mathbf{3}$ & 11.25 & 50.00 \\
$\mathbf{3 - 4}$ & 47.50 & 15.00 \\
$\mathbf{5 - 6}$ & 15.00 & 11.25 \\
$\mathbf{7 - 8}$ & 12.50 & 15.50 \\
$\mathbf{> 8}$ & 6.25 & 3.75 \\
Unknown & 7.50 & 5.00 \\
\hline
\end{tabular}

None of the farmers consistently apply fertilizer to their cocoa due to alleged high cost of fertilizer. Fertilizer was normally applied between 2 to 5 years intervals, although farmers reportedly attain significant yield increments whenever they were applied: average yield of dry beans for non-fertilizer and fertilizer enriched fields were 118 and $298 \mathrm{~kg} /$ acre/annum respectively.

The farmers themselves and their household were the predominant labour force in all farm activities (Table 4a and b). Manual weeding, where men were mostly hired, was the primary weed management option for cocoa, due to the fear that herbicides may affect the longevity of the cocoa trees (Table 4a). In the supplementary farms, both manual and herbicides were employed (Table 4b). Women and children (mostly above 10 years old) were mostly involved in collection and breaking of pods for cocoa farms (Table 4a) and harvesting in supplementary farms, particularly vegetables (Table $4 \mathrm{~b}$ ). They also assisted in pesticide application by fetching water for the applicators in all farms. 
Table 4a. Labour distribution in the cocoa farm

\begin{tabular}{|c|c|c|c|c|c|c|c|c|}
\hline \multicolumn{9}{|c|}{ Farm activity (percent responses) } \\
\hline \multirow[t]{2}{*}{ Type of labour } & \multicolumn{2}{|c|}{ Weed control } & \multirow{2}{*}{$\begin{array}{l}\text { Fertilizer } \\
\text { application }\end{array}$} & \multirow[t]{2}{*}{ Pruning } & \multirow{2}{*}{$\begin{array}{l}\text { Insecticide } \\
\text { application } \\
\end{array}$} & \multirow[t]{2}{*}{ Harvesting } & \multirow{2}{*}{$\begin{array}{l}\text { Pod } \\
\text { Gathering }\end{array}$} & \multirow{2}{*}{$\begin{array}{l}\text { Pod } \\
\text { Breaking } \\
\end{array}$} \\
\hline & Manual & Herbicide & & & & & & \\
\hline Own & 40.0 & 60.1 & 81.9 & 78.0 & 72.8 & 81.9 & 40.0 & 81.9 \\
\hline Family (men) & 15.6 & 20.6 & 30.3 & 42.0 & 42.0 & 20.5 & 30.5 & 30.5 \\
\hline Family (women) & 18.2 & 53.0 & 24.3 & 0 & 53.0 & 10.0 & 60.0 & 60.0 \\
\hline Family (children) ${ }^{\mathrm{a}}$ & 12.8 & 30.5 & 30.5 & 0 & 30.5 & 10.0 & 38.0 & 30.5 \\
\hline Help by friends & 7.0 & 0 & 0 & 0 & 0 & 0 & 0 & 50.2 \\
\hline Exchange labour $^{\mathrm{b}}$ & 4.7 & 0 & 0 & 0 & 0 & 0 & 0 & 85.0 \\
\hline Hired labour $(m e n)^{c}$ & 52.3 & 24.8 & 0 & 52.0 & 60.3 & 40.2 & 0 & 0 \\
\hline Hired labour (women) ${ }^{c}$ & 0.0 & 0 & 0 & 0 & 20.0 & 0 & 21.7 & 0 \\
\hline Hired labour (children) & 0.0 & 0 & 0 & 0 & 0 & 0 & 0 & 0 \\
\hline
\end{tabular}

${ }^{a}$ Mainly older children (usually beyond primary school) on Saturdays and vacations.

${ }^{b}$ Neighbouring farmers are mobilized for a specific task in one of the members' farm, as and when the need arises. No cash payment is made but the beneficiary needs to provide food.

${ }^{\mathrm{c}}$ Labour considered as cost by farmers.

Table 4b. Labour distribution in supplementary farms

\begin{tabular}{lcccll}
\hline \multicolumn{7}{c}{ Farm activity (percent responses) } \\
\hline \multirow{2}{*}{ Type of labour } & \multicolumn{2}{c}{ Weed control } & $\begin{array}{l}\text { Fertilizer } \\
\text { application }\end{array}$ & $\begin{array}{l}\text { Pesticide } \\
\text { application }\end{array}$ & Harvesting \\
\cline { 2 - 5 } & Manual & Herbicide & & \\
\hline Own & 80.0 & 72.0 & 100 & 93.0 & 100 \\
Family (men) & 61.3 & 61.0 & 42.9 & 50.4 & 49.0 \\
Family (women) $^{\mathrm{a}}$ & 53.1 & 53.0 & 21.2 & 76.4 & 58.3 \\
Family (children) $^{\mathrm{a}}$ & 4.0 & 23.3 & 0 & 45.0 & 22.8 \\
Help by friends $^{\mathrm{b}}$ & 0 & 0 & 0 & 0 & 0 \\
Exchange labour $^{\mathrm{b}}$ & 0 & 0 & 0 & 0 & 0 \\
Hired labour (men) $^{\mathrm{c}}$ & 32.0 & 44.0 & 0 & 34.0 & 0 \\
Hired labour (women) $^{\mathrm{c}}$ & 0 & 0 & 0 & 10.0 & 8.0 \\
Hired labour (children) & 0 & 0 & 0 & 0 & 0 \\
\hline
\end{tabular}

The risk for these women and children were the fact that they usually stay in the farms during spraying without any personal protective equipment. The women and children also helped in weeding farms, but the latter were mostly engaged during weekends and school vacations. Although family labour was important, these were not considered as cost and thus excluded from farm expenditure. Only hired labour where physical cash was paid for services were priced. No hired child labour was recorded and hired women covered only water fetching, cocoa pod gathering and occasionally vegetable harvesting.

The three top expenditure on cocoa and vegetables were fertilizer, pesticides (insecticide \& fungicide) and harvesting (Table 5) whilst the topmost expenditure for plantain/oil palm and cassava/maize were herbicide application and harvesting. The seeming high cost of harvesting was due to the high frequency of undertaking the activity in a year. The low values recorded for pod gathering and breaking in cocoa farms despite a link to harvesting was because a single day was used after harvesting for a couple of days. No insecticide usage was recorded for cassava/maize because the fall armyworm invasion had not caught up with the area at the time of the survey. 
Table 5. Costs of routine farm activities

\begin{tabular}{lllll}
\hline \multirow{2}{*}{ Activity } & \multicolumn{5}{c}{ Mean cost/acre/year (GHS) } \\
\cline { 2 - 5 } & Cocoa & Vegetable & Plantain/ oil palm & Cassava/ maize \\
\hline Manual weeding & 24 & 36 & 44 & 37 \\
Herbicide application & 0 & 12 & - & 54 \\
Fertilizer application & 122 & 58 & - & 30 \\
Pruning & 12 & - & - & - \\
Insecticide \& fungicide application & 44 & 96 & - & - \\
Harvesting & 72 & 90 & 24 & 48 \\
Pod gathering & 36 & - & - & - \\
Pod breaking & 36 & - & - & - \\
Total & $\mathbf{3 4 6}$ & $\mathbf{2 9 2}$ & $\mathbf{6 8}$ & $\mathbf{1 6 9}$ \\
\hline
\end{tabular}

*Exchange rate: US $\$ 1.00=$ GHS4.40

The total cost of farm maintenance activities per acre of cocoa with and without fertilizer were GHS 346 and GHS 224 respectively. The expenditures on supplementary crops comprising vegetables, plantain/oil palm and cassava/maize per year were GHS 292, GHS 68 and GHS 169 respectively (Table 6). It must be emphasized that although costs were calculated in monetary terms, by converting man working hours where necessary, not all labour was paid with physical cash. Fertilizer application, for instance, was undertaken by farmers and their household while pod breaking involved farmers and their household as well as friends and exchange of labour, depending on the farm size or yield. In the exchange of labour, however, food was provided to the collaborators. Weeding, pruning and insecticide spraying were either carried out by farmers household (in which case it is cost free) or by hiring labour whereby physical cash was paid.

Additional variable costs (categorised as miscellaneous costs) covering fermenting, drying of cocoa beans, cutlass, transportation of produce to sales depot (for cocoa) and markets etc. for cocoa, vegetables, plantain/oil palm and cassava \& maize were GHS 209, GHS 70, GHS 85 and GHS 68 respectively.

Table 6. Cost and income of managing cocoa and supplementary farms

\begin{tabular}{lcccc}
\hline Variable & \multicolumn{4}{c}{ Cost \& income/acre/year GHS (US\$) } \\
\cline { 2 - 5 } & Cocoa & Vegetable & Plantain/ oil palm & Cassava \& maize \\
\hline Total variable costs & 555 & 362 & 153 & 237 \\
Total revenues & 1392 & 636 & 401 & 399 \\
Variable margin & $\mathbf{8 3 7}$ & $\mathbf{2 7 4}$ & $\mathbf{2 4 8}$ & $\mathbf{1 6 2}$ \\
\hline
\end{tabular}

Exchange rate of US $\$ 1.00=$ GHS4.40 at time of survey.

Yearly variable margin of GHS 837, GHS 272, GHS 248 and GHS 162 were accrued from an acre of cocoa, vegetables, plantain/oil palm and cassava and maize respectively. The variable margin from cocoa based on the modal farm size of 3-4 acres (Table 3) was GHS 2,511-3,348. That of supplementary crops of modal farm size 0.5-2.5 acres was GHS 137-685, GHS 124-620 and GHS 81-405 with respect to vegetables, plantain/oil palm and cassava/maize. The variable margin of half of the farmers $(50 \%)$ per year, depending on the type of supplementary crop, was GHS 2,591-3,753 (US\$ 589-853). With the inconsistent use of fertilizer on cocoa (the major crop), this amount reduces to GHS $1647-2,195$ (US\$ 474-499) for the periods that fertilizer was not applied.

\section{Discussion}

The dominance of males in cocoa cropping is typical of tree crop cultivation and this is influenced mostly by the land ownership system. Thus, males tend to be heads of families and land rights are normally reposed in them and therefore have the opportunity of establishing perennial crops on such lands as family property. The low educational levels of the farmers corroborate other findings (Frimpong-Anin, Kwapong \& Gordon, 2013). It reflects the low levels of education in rural communities and the migration of the educated to urban areas.

Formal farm record keeping was generally low but most farmers could keep track of some expenses such as direct labour hiring, pesticides, fertilizer and transport. From these, cumulative expenditure over the year was estimated. Costing farm labour was a challenge as farmers were selective in what was considered cost that must be accounted for. Labour was priced only when physical cash was paid by the farmer and thus labour by farmers' 
household and friends were normally unaccounted for. Consequently, farmers who were unable to use personal and household labour due to old age or other factors but hire labour tend to give relatively accurate farm expenditure. Among this group for instance, labour was usually hired for weeding, insecticide application (and pruning and sometimes harvesting in the case of cocoa). For this group, picking and breaking pods were the activities that did not employ hired labour. In the case of share crop of cocoa, all labour was provided by the caretaker and the household with occasional help from friends or exchange labour. In some instances (especially in relatively larger farms) labour was hired by the owner to complement that of the caretaker. On the part of the caretaker, there was no recognizable expenditure and thus the only billed expenditure was cost of pesticide application and farm tools which were borne by the landowners.

Management of insect pests on cocoa and vegetables were major challenges faced by farmers. Cocoa farmers were a bit relieved due to mass spraying cocoa with pesticides by the government, albeit the inconsistencies of spraying. Farmers also claim they were unable to complement the mass spraying as expected of them due to cost of insecticide and difficulty in hiring mistblowers. These farmers therefore resort to manual knapsack, which may not be efficient in treating the canopy, especially among taller cocoa trees. This means the mass spraying significantly reduces expenditure on pest management.

Beside cost, selecting the appropriate insecticide for a particular pest is also a problem to vegetable growers. The use of insecticides, in particular, recommended for cocoa are commonly applied to vegetables without any consideration to suitability and post spraying and harvesting intervals. This was based on the premises that once it works against cocoa pest, it is appropriate for all other crop pests. Similar to observation by Frimpong, (2019), several people, including children, assisted in the insecticide spraying exercise but only the sprayers wore protective gear, which in most cases were even inadequate. All persons directly involved in the spraying exercise must therefore be encouraged to wear protective gear as excessive exposure to insecticides has serious health implications. This may drain the scarce resources of the household due to increased health bills.

The high proportion of farmers having alternative sources of income is commendable, as this will be a guarantee in the case of failure of their prime income source, cocoa. However, the small size (3-4 acres) of most of the cocoa farms and the total earnings of GHS 2,511-3,348 (GHS 837/acre/year) and GHS 81-685 from the supplementary crops (depending on farm size and type of crops) relative to the common household size of 4-6 individuals is inadequate. Furthermore, fewer members of the household, besides the heads, generated income to support the family. The $23 \%$ of farmers with no alternative income is high and poses further challenge in the quest to reduce extreme poverty in farming communities. In this regard, farmers must be encouraged to embrace new policies in the agricultural sector through reinforced extension services and civic education on government policies. Through this, farmers can intensify production in order to increase their fortunes. The use of fertilizer, which farmers attested increase yield by $144 \%$, appear to be very important input in cocoa cultivation although most farmers did not consistently applied it. This was attributed to the high cost of the fertilizer and similar results was obtained by Nunoo et al. (2014). The prices of fertilizers have since been halved through the Ghana government's programme on planting for food and jobs and therefore higher yield is expected in years ahead. The high increment in the yield of cocoa upon applying fertilizer suggests fertility of the soils is low and thus there is the need to introduce a more sustainable production strategies. This was evident in the observed yield increment of up to $100 \%$ in cropping seasons when fertilizer was applied. It must be indicated that traditionally, vegetable and maize growers consistently use fertilizers (although below the recommended quantities) but not for cassava, plantain and oil palm. As observed by Mintah et al. (2017), however, crop such as plantain that is not traditionally treated with fertilizer responds well to fertilizers and must be encouraged.

It was also observed that the household heads who earned regular salary mostly owned share crop farms - in the share crop arrangement, owner is entitled to two-third of gross dry bean yield whilst the caretaker takes one-third. This means the actual income for the caretaker is paltry. The share crop constituted $32 \%$, meaning almost a third of the farmers were caretakers, whose earnings must be improved. From the foregoing, alternative supplementary income programmes should also be a priority, especially for women in these settings. This suggest that other income generating ventures such as snail rearing, livestock, mushroom and bee keeping that require low input and short duration of training must be promoted among household of these smallholder farmers.

\section{Conclusion}

Labour from farmers' household was very important in cocoa production but was not normally priced as cost and thus most farmer returns were lesser than what they were purported to be. Farmers need to be re-oriented to be business minded in managing farms. The variable margin of GHS 837 and 162-274/acre/year from cocoa 
(without fertilizer) and supplementary crops respectively were inadequate, considering the household size.: Thus, although majority of the farmers have alternative sources of income, this was inadequate to sustain their households and therefore more intervention is needed. Fertilizer application substantially increased yield and variable margin. Farmers must therefore embrace its use, particularly now that it is highly subsidized by government.

\section{References}

Acquaah, B. (1999). Cocoa development in West Africa: Early development with special reference on Ghana. Ghana Universities Press, Accra. pp. 187.

Aneani, F., Anchirinah, V. M., Owusu-Ansah, F., \& Asamoah, M. (2012). Adoption of some cocoa production technologies by cocoa farmers in Ghana. Sustainable Agriculture Research, 1(1), 103-117. https://doi.org/10.5539/sar.v1n1p103

Appiah, M. R. (2004). Impact of cocoa research innovations on poverty alleviation in Ghana. Ghana Academy of Arts and Sciences. pp. 22.

Buffin, D., Williamson, S., \& Dinham, B. (2004). Lindane use in West Africa. Pesticide Management in West Africa, 4, 35-39.

Frimpong, E. A. (2009). Management of wild pollinator services in cocoa production systems in Ghana. Ph.D. Thesis. University of Cape Coast, Cape Coast, Ghana \& ICIPE, Nairobi, Kenya.

Frimpong-Anin, K., Kwapong, P. K., \& Gordon, I. (2013). Cocoa farmers awareness of pollination and its implication for pollinator-friendly practices. Research and Reviews in Biosciences, 7(12), 504-512.

Ghana Cocoa Board (COCOBOD). Retrieved from https://cocobod.gh/home_section.php?sec=1

Ghana Statistical Service (2013). Population in agriculture. In 2010 National Population and Housing Census: Analytical Report. pp. 287-304. Retrieved from www.statsghana.gov.gh/docfiles/.../2010_PHC_National_Analytical_Report.pdf

Hainmueller, J., Hiscox, M. J., \& Tampe, M. (2011). Sustainable development for cocoa farmers in Ghana. Working paper, International Growth Center.

Laven, A. C. (2010). The risks of inclusion: shifts in governance processes and upgrading opportunities for cocoa farmers in Ghana Amsterdam: KIT publishers. Retrieved from https://pure.uva.nl/ws/files/1437472/77981_18.pdf

Mintah, P., Frimpong-Anin, K., Oppong, J., \& Annor, B. (2017). Exploiting organic waste and inorganic fertilzer for sustainable production of Plantain (Musa Spp.) in Ghana. Journal of Global Agriculture and Ecology, 7(2), 82-90.

Nunoo, I., Frimpong, B. N., \& Frimpong, F. K. (2014). Fertilizer use among cocoa farmers in Ghana: the case of Sefwi Wiawso District. International Journal of Environment, 3(1), 22-31. https://doi.org/10.3126/ije.v3i1.9939

\section{Copyrights}

Copyright for this article is retained by the author(s), with first publication rights granted to the journal.

This is an open-access article distributed under the terms and conditions of the Creative Commons Attribution license (http://creativecommons.org/licenses/by/3.0/). 